\title{
SELF-ENHANCEMENT AND COPING: THE COSTS AND BENEFITS OF POSITIVE ILLUSIONS
}

\author{
Jacek NECKAR \\ Institute of Psychology, Jagiellonian University \\ al. Mickiewicza 3, Kraków, 31-120, Poland \\ E-mail: jacek.neckar@uj.edu.pl
}

\begin{abstract}
The relation between self-enhancement and psychological adjustment has been controversial and so far open to debate since the influential paper of Taylor and Brown (1988). In the current investigation the relationship between two measures of self-enhancement (narcissism and over-claiming) and coping (constructive thinking) in a sample of young, healthy adults $(\mathrm{N}=168)$ was examined. The structural model showed an equally strong relation of self-enhancement to good and poor coping, thus confirming the hypothesis that self-enhancement has both adaptive and maladaptive effects. The different patterns of relations between two measures of selfenhancement and coping were also detected, which corroborates the idea that the controversy regarding the adaptive value of self-enhancement is to a large extent caused by different measures of self-enhancement.
\end{abstract}

Key words: self-enhancement, narcissism, coping

\section{INTRODUCTION}

During the last 20 years, compelling evidence has accumulated that demonstrates the tendency of individuals to hold unrealistically positive self-evaluations (for reviews see Chang, 2008; Heine, Buchtel, 2009). There is little doubt that people tend to regard themselves as better than they are in reality, but questions remain regarding the relation between this tendency and psychological adjustment. Taylor and Brown (1988) have provided evidence of the adaptive value of holding positive illusions, including un-

Acknowledgements: Portions of the data from this study were presented at the $12^{\text {th }}$ European Conference on Personality, July 2004, Groningen, Netherlands. realistically optimistic perceptions of oneself. Other researchers have produced contradictory data and argue that either self-enhancement is definitely maladaptive (Colvin, Block, Funder, 1995) or it has a short-term adaptive value, but in the long term, is totally maladaptive (Robins, Beer, 2001). The general aim of the study presented herein was to contribute to the debate on the adaptive value of self-enhancement.

The most explicitly positive view of a selfenhancing person has been defended by Taylor and her colleagues (Taylor, Sherman, 2008). They have reviewed existing evidence and collected data suggesting that self-enhancement is associated with several abilities such as the ability to feel good about oneself, the ability to create a firm relationship, the capacity for creative work, and the ability to achieve long-term goals (Taylor et

DOI: $10.21909 / \mathrm{sp} .2013 .04 .644$ 
al., 2003). Apart from the beneficial effects of self-enhancement that have been proposed by Taylor and Sherman (2008), other studies have repeatedly demonstrated the adaptive value of this phenomenon. One example is Foster and Campbell's (2005) research on the positive influence of narcissism on romantic relationships. Two other studies (Otter, Egan, 2007; Surbey, 2011) revealed a positive relation between self-enhancement and the tendency to cooperate.

The critics of a clear-cut adaptive nature of self-enhancement often indicate that the individual advantages of self-enhancers sometimes are at the cost of social dislikes (von Hippel, Trivers, 2011). Some of the most widely accepted research that indicates the disadvantageous effect of self-enhancement focuses on the social (peer) perception of self-enhancers (Colvin et al., 1995; Robins, Beer, 2001). In an important longitudinal study (Colvin et al., 1995), the self-enhancers were less liked by peers after four years of college and had more problems with achieving a long-term goal (i.e., graduating) than the low self-enhancing students. There is also some data indicating the intrapersonal costs of self-enhancement. Baumeister and his colleagues showed higher level of imprudent risk-taking among self-enhancers (Baumeister, Heatherton, Tice, 1993), whereas Oettingen and Gollwitzer (2002) discovered that self-enhancement is related to ineffective planning.

The inconsistent results of research on self-enhancement and adjustment have led several researchers to hypothesize that selfenhancement has both adaptive and maladaptive effects (Hoorens et al., 2012; Kwan, Kuang, Zhao, 2008; Paulhus, 1998). In support of this claim, Paulhus (1998) reported the mixed effects of self-enhancement on various aspects of performance and adjustment that were rated by peers several times during a 2-month acquaintance. The selfenhancers made a better impression than non-self-enhancers at the first meeting. However this effect was reversed at the last meeting after two months. Paulhus (1998) suggested that possible reasons for the diminished appeal of self-enhancers were connected with their hostility and lack of warmth.

When analyzing the effects of self-enhancement on adjustment, the criterion of adjustment needs to be specified. Taylor and Brown (1988) proposed four mental health criteria, three of which correspond roughly to three aspects of adjustment described by Kwan et al. (2004), i.e., happiness, the quality of interpersonal relationships, and achievement. The fourth criterion proposed by Taylor and Brown as "persistence at tasks, and ultimately, more effective performance" (1988, p. 199) was recently reformulated by Marshall and Brown (2008, p. 20) as "the capacity to face life's challenges and potentially grow from them". This criterion has been found to be positively related to self-enhancement in various groups such as civilians from Bosnia exposed to extreme stress, conjugally bereaved Californians (Bonanno et al., 2002), and survivors of the September $11^{\text {th }}$ terrorist attack (Bonanno, Vitaro, Dekel, 2005). Taylor and collaborators (Taylor et al., 2000; Taylor et al., 2003) have also found that unrealistically positive selfperception is a potential resource that becomes especially useful in extreme situations such as suffering a severe, chronic illness. However, two questions remain to be answered. The first question is whether the positive relationship between self-enhancement and effective coping holds only for extreme situations or can be generalized into 
everyday difficult and stressful situations. The second question is whether self-enhancement has only a beneficial effect on coping, or, as in other aspects of adjustment previously studied, it might also negatively influence coping.

Choosing a coping scale is a particularly difficult task. There is a plethora of different measures of coping that grasp either dispositional or episodic aspect of coping (for a review see Skinner et al., 2003; Steed, 1998). A very common choice of researchers has been the COPE scale (Carver, Scheier, Weintraub, 1989). However, the scale has a serious weakness: there is no clear distinction between adaptive and maladaptive coping strategies that the scale measures. For the present research, a general domain scale of coping, the Constructive Thinking Inventory(CTI, Epstein, Meier, 1989; Epstein, 1993) has been chosen for its two crucial characteristics. Most importantly, it clearly identifies and separately measures adaptive and maladaptive coping. In addition, it multidimensionally measures the construct, i.e., it focuses on both cognitive and emotional processes that either promote or jeopardize coping. Epstein (1993; Epstein, Meier, 1989) has conceptualized adaptive coping as the ability to approach everyday problems in ways that promote their solution at minimal cost in stress (Epstein, 1990). It can be thus defined as the degree to which a person's automatic thinking which occurs without deliberate intention facilitates solving problems. An example of adaptive coping is viewing situations as challenges rather than threats (Epstein, 1993). The construct is rooted in the Cognitive-Experiential Self Theory (Epstein, 2003).

The CTI was designed to measure constructive and counterproductive responses that people report having in everyday life. The source of CTI items referring to adaptive coping strategies (constructive responses) and maladaptive coping strategies (counterproductive responses) were students' reports depicting their reaction to stressful situations and the records of cognitive therapy practice (Beck, 1976; Ellis, 1962). Substantial evidence has been gathered to suggest the validity of CTI as a measure of general coping ability (Epstein, 1992; 1993; Katz, Epstein, 1991; Scheuer, Epstein, 1997). The CTI has not been used in the context of analyzing the adaptive value of selfenhancement, but given its two crucial characteristics, it is well suited to the purpose of analyzing presumably complex and mixed effects of self-enhancement on adjustment.

Another important issue in the research on the adaptive value of self-enhancement is the choice of self-enhancement measure. A frequent way of assessing self-enhancement was to use ratings of global qualities of the self in comparison with others (Taylor, Gollwitzer, 1995). One of the weaknesses of this approach is the presence of non-motivational, i.e., purely cognitive, factors that influence the comparative judgment that a person is better than others (Alicke, Govorun, 2005). To overcome the shortcomings of the self-report measures of self-enhancement, a more objective way of assessment by an observer has been developed. In this approach, self-enhancement is operationalized as the overestimation of one's positivity relative to an observer judgment. However, the method is not entirely free from weaknesses. The observer can be also biased and, more importantly, there is a problem of measuring the difference between selfrating and criterion: it can be a raw difference or a residual self-rating after the crite- 
rion was removed. Some critics suggest that neither procedure avoids problems with reliability (Paulhus et al., 2003). Another weakness of the observer criterion method is its impracticality in the standard administration settings.

A common solution to the problem of selfenhancement assessment has been using a measure of non-pathological narcissism, which is a good correlate of self-enhancement (John, Robins, 1994; Paulhus, 1998). In general, the Narcissistic Personality Inventory (NPI, Raskin, Terry, 1988) captures those aspects of self-enhancement that involve very optimistic attitude toward oneself and one's abilities. Although narcissism encompasses both positive emotions and positive thinking about oneself, research suggests that it reflects predominantly the emotional side of self-enhancement. For instance, narcissism has been shown to influence selfesteem through the self-conscious emotions such as pride, guilt and shame (Uji, Nagata, Kitamura, 2012). It also had the moderational effect on emotional reactions to success and failure (Rhodewalt, Morf, 1998).

A quite different approach to the measurement of self-enhancement has been proposed by Paulhus and his collaborators (Paulhus et al., 2003) in their Over-Claiming Questionnaire (OCQ). OCQ measures self-enhancement by assessing cognitive reactions to situations in which participants are asked whether they possess knowledge that does not exist (e.g., knowledge about plates of parallax). It reflects how participants actually think and cognitively cope with a task rather than what they feel about themselves. Thus, in contrast to the Narcissistic Personality Questionnaire, which seems to capture predominantly self-reported emotional aspects of self-enhancement, OCQ objectively captures cognitive processes. High scores on OCQ reflect decisions based on the feeling of familiarity (there is a concept of parallax in astronomy) and the assumptions that "I probably know enough about it", without any thorough searching through one's knowledge. This kind of cognitive processing results in claiming knowledge and competences that one does not possess.

The main objective of this study was to analyze the relationship between self-enhancement and adjustment. On the basis of the criteria of mental health and adjustment provided by Taylor and Brown (1988) and Marshall and Brown (2008), I chose the ability to cope effectively with stressful situations as a criterion of adjustment. In accordance with Paulhus (1998) and Kurt and Paulhus (2008), I predicted that self-enhancement would play both positive and negative role in adjustment, i.e., it would assure both benefits and costs in adjustment. I also expected that different methods of measuring self-enhancement would reveal different aspects of relationships between self-enhancement and coping.

More specifically, I expected that the Narcissistic Personality Questionnaire, which stresses positive feelings about oneself and positive self-evaluations, would predict emotional coping (as measured by the Emotional Coping Scale of CTI). Emotional coping describes constructive responses to difficult situations in which an individual is positive about the future and avoids dwelling on negative emotions. This would indicate the beneficial effect of having very optimistic view of oneself. As to the cost of self-enhancement, I expected the NPI to predict being overtly and unrealistically optimistic (as measured by the Naive Optimism Scale of CTI). This refers to counterproductive 
responses in which the evaluations of oneself, other people and the world in general are so positive that they distort the perception of a difficult situation and inhibit searching for an effective solution. The Over-Claiming Questionnaire, which objectively captures cognitive processes when completing a task, was expected to predict behavioral coping (as measured by the Behavioral Coping Scale of CTI). Behavioral Coping describes constructive thinking about difficult situations that promotes effective action. It includes emphasizing positive aspects of a situation and an opportunity to learn, readiness to act and confidence that actions will be effective. As to the cost of self-enhancement, I expected the OCQ to predict inadequately positive thinking when individuals see opportunities that actually do not exist and claim to have abilities that they do not actually have. Specifically, I expected the Esoteric Thinking Scale of CTI to be related to OCQ scores, as it measures a lack of critical thinking and excessive reliance on unsubstantiated impressions.

\section{METHOD}

\section{Participants}

One hundred and sixty eight undergraduates from various humanities and technical faculties of universities in southern Poland volunteered to participate. The study included 93 women and 75 men (mean age $=$ 20.51 , standard deviation $(S D)=0.88)$.

\section{Measures}

CTI. The CTI is a self-report personality inventory that measures the ways in which people usually react on cognitive, emotional, and behavioral levels to emotionally significant experiences, such as failure, rejection or disapproval. The CTI provides scores for a global scale (GCT) and six specific scales. Emotional Coping (EC) and Behavioral Coping (BC) measure adaptive coping. High scores on EC are associated with self-acceptance ("I do not feel that I have to perform exceptionally well in order to consider myself a worthwhile person"), low sensitivity to failures ("I do not let little things bother me"), and the absence of dwelling on adverse experiences ("I tend to dwell more on pleasant than unpleasant incidents from the past"). High scores on BC are associated with positive thinking ("I believe it is best, in most situations, to emphasize the positive side of things") and action-orientation ("I am the kind of person who takes action rather than just thinks or complaints about the situation"). Naive Optimism (NO), Esoteric Thinking (ET), Personal Superstitious Thinking (PST) and Categorical Thinking (CT) measure maladaptive coping. High scores on $\mathrm{NO}$ are associated with unrealistic optimism and a failure to face unpleasant realities (e.g., "If I do well on an important test, I feel like a total success and that I will go far in life", "When something good happens to me, I feel that more good things are likely to follow"). High scores on ET are related to faith in unusual and scientifically questionable phenomena that can lead people to behave unrealistically (e.g., "I believe if I think terrible thoughts about someone, it can affect that person's well-being", "I believe if I wish hard enough for something, it can make it happen"). People scoring high on PST endorse superstitions that are oriented toward defending them against threat and disappointment rather than helping them in personal fulfillment (e.g., the belief that if you 
want something to happen too badly, it will keep it from happening or if something very good happens, it will be balanced by something equally bad). People scoring high on $\mathrm{CT}$ view the world in black and white terms and think rigidly, which makes them prone to feelings of annoyance and anger when their beliefs are undermined. A 108-item Polish version of the CTI was developed in cooperation with Epstein (Neckar, 2000). The reliability of CTI scales were as follows EC $\alpha=$ $0.91, \mathrm{BC} \alpha=0.75$, PST $\alpha=0.67, \mathrm{CT} \alpha=0.70$, ET $\alpha=0.78, \mathrm{NO} \alpha=0.72$.

Over-Claiming Questionnaire (OCQ). The Polish version of the 90-item OCQ (Paulhus et al., 2003) was developed in cooperation with Paulhus. The OCQ is a criterion-based measure of self-enhancement. The respondents assess their familiarity with historical or literary names and scientific notions. There are six categories of knowledge with each including 15 items. In each category, three items are foils, i.e. non-existent items (e.g., cholarine) and twelve items refer to existing knowledge (e.g., hydroponics). As in Paulhus's version of the OCQ, two indexes were calculated in the Polish version using signal detection theory (Macmillan, Creelman, 2005). The rating accuracy (OCQ accuracy) was calculated using the widely used sensitivity measure, $d$. The response bias (OCQ bias) was calculated using a crude measure, namely, the false alarm rate and a basic measure for detection theory, namely, the criterion location, $c$. The reliability of 72 real items and 18 foil items were: $\alpha=0.94$ and $\alpha=0.77$, respectively.

Narcissistic Personality Inventory (NPI). A 40-item version of the NPI was used in the present study. It was developed by Raskin and Terry (1988). The items had a forced choice format. The inventory was translated into Polish by the present author. In this study, the scores ranged from 4 to $34(\mathrm{M}=$ $18.07, \alpha=0.81$ ).

\section{Procedure}

The participants were tested in groups of approximately 20 . They were initially informed that the researcher was interested in the possible links between personality and preference for or expertise in various domains of knowledge. They were later informed about the true nature of the OCQ and the real research goal.

\section{RESULTS}

Data was analyzed using SPSS 20.0. The Pearson's correlation between the two measures of self-enhancement was insignificant $(r=.11, p=.14)$. The pattern of zero-order correlations between the NPI and the OCQ and the subscales of the CTI are presented in Table 1. A series of hierarchical regres-

Table 1. Pearson's product-moment correlations between measures of self-enhancement: (Over-Claiming Questionnaire and Narcissistic Personality Inventory) and coping: (Emotional Coping, Behavioral Coping, Naive Optimism, Personal Superstitious Thinking, and Esoteric Thinking)

\begin{tabular}{|l|l|l|l|l|l|l|}
\hline & EC & BC & NO & CT & PST & ET \\
\hline OCQ & .08 & $.19^{*}$ & .02 & .01 & $-.37^{* *}$ & $.18^{*}$ \\
\hline NPI & $.20^{* *}$ & $.30^{* *}$ & $.29^{* *}$ & $.24 * *$ & .01 & .04 \\
\hline
\end{tabular}

Note: $* \mathrm{p}<.05 ; * * \mathrm{p}<.01$ 
sions were calculated separately for two indicators of good adjustment (BC and EC). The hierarchical regression was used to assess the relative importance of two measures of self-enhancement and to judge how much the second predictor adds to the prediction of the criterion. As I assigned the so-called causal priority (Cohen et al., 2003) to more objective measure of self-enhancement, i.e., the OCQ, it was selected as the first step in the hierarchical analyses. The NPI was introduced in the second step. For Emotional Coping only NPI was a significant predictor, and explained $4 \%(\mathrm{~F}(1,165)=6.66, \mathrm{p}<0.05$; $\beta=.20$ ) of the variance in the dependent variable. For Behavioral Coping both predictors were significant: OCQ explained $3.5 \%$ of the $\mathrm{BC}$ variance $(\mathrm{F}(1,166)=5.97, p<0.05 ; \beta=.19)$ and NPI added $8 \%$ more $(\mathrm{F}(1,165)=14.80$, $\mathrm{p}<0.001 ; \beta=.28)$. The second series of analyses was conducted in a similar manner with the four indicators of poor adjustment in the CTI as the dependent. For Naive Optimism and Categorical Thinking only NPI was a significant predictor and explained $9 \%(\mathrm{~F}(1,165)$ $=15.30, \mathrm{p}<0.001 ; \beta=.29)$ and $6 \%(\mathrm{~F}(1,165)=$ $9.76, \mathrm{p}<0.01 ; \beta=.24)$ of their variance respectively. In the case of Esoteric Thinking only OCQ was significant and explained 3\% of the variance $(\mathrm{F}(1,166), \mathrm{p}<0.05 ; \beta=.18)$. Similarly for Personal Superstitious Thinking, the OCQ was the only significant predictor and accounted for $14 \%$ of the variance $(F(1,166)=26.25, p<0.001 ; \beta=.-37)$, beta of OCQ was negative in this case.

To provide a broader picture of relations between two measures of self-enhancement and various indicators of good and poor coping, a structural equation model was designed. Since the good and poor coping indicators largely overlapped (Pearson's correlations ranged from 0.18 to 0.60$)$, two la- tent variables were proposed in the path model: good coping and poor coping. The entire model had poor to marginally acceptable fit: $\mathrm{CMIN} / \mathrm{DF}=3.63$; $\mathrm{CFI}=0.76$ and $\mathrm{RMSEA}=0.12$. However testing the entire model was less important than demonstrating that pattern of covariance between latent variables and self-enhancement reflected the covariance between each indicator of coping and the self-enhancement. Regression weights for the NPI were significant and nearly equal for both the good and poor coping latent variables (Figure 1). In contrast, the OCQ weight was significant only for good coping. Overall, the path analysis showed the pattern of effects very similar to that obtained in the series of hierarchical regressions.

\section{DISCUSSION}

The study described herein investigated adaptive aspect of self-enhancement, with adjustment measured as an ability to cope successfully with stressful situations. Selfenhancement was measured subjectively, with the NPI which assesses the self-perceived value of a person, and objectively, with the criterion-based OCQ which captures the exaggeration of knowledge.

As expected, self-enhancement was a significant predictor of both adaptive and maladaptive coping strategies. The self-enhancement measures were related to the constructive and counterproductive coping scales of the CTI with a comparable strength. The optimistic side of self-enhancement apparently promotes coping with difficult and stressful events at minimal costs, but there is also a weakness in that tendency, which is a risk of relying more on the imagined positive nature of oneself than perceiving and 
behaving realistically. This finding is in agreement with the results of previous studies, which revealed the two sides of self-enhancement (Kurt, Paulhus, 2008; Paulhus, 1998; Robins, Beer, 2001). It also extends previous evidence in two important respects. The results indicate that the same adjustment criterion, i.e., an ability to cope with stressful situations, can reveal both benefits and costs of self-enhancement. Second, the pattern of results suggests that self-enhanc- ers can have considerable costs at the intraindividual level.

The pattern of results substantially corroborated the expectation that the level of narcissism would be related to those aspects of coping that involve mainly emotional responses to difficult situations, whereas the level of knowledge exaggeration would be predominantly related to cognitive coping. As expected, emotional coping and naive optimism were predicted only by narcissism.

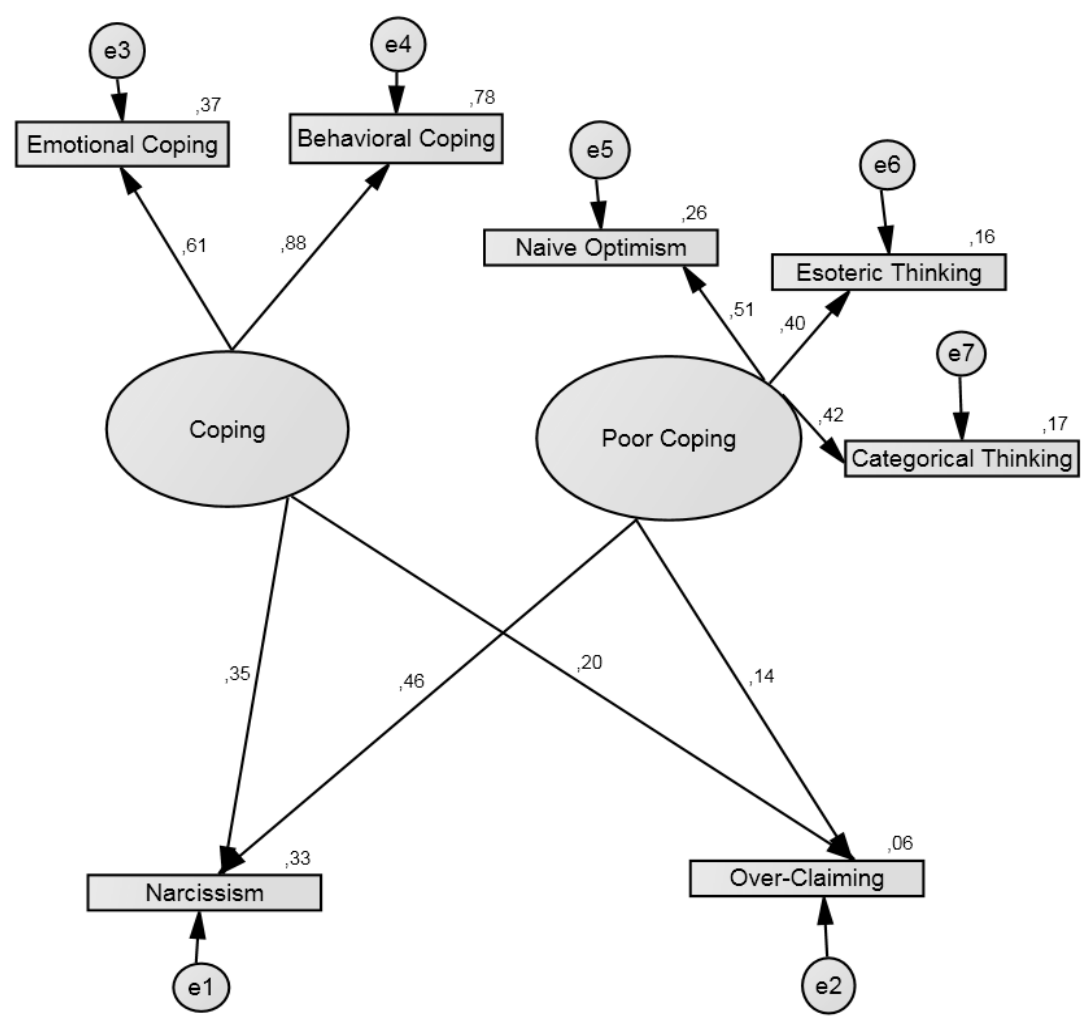

Figure 1. Structural model of self-enhancement and coping. The numbers close to the arrows indicate standardized regression weights. The numbers placed above the name of the variables indicate squared multiple correlations. 
In contrast, the level of knowledge exaggeration predicted only behavioral coping and esoteric and superstitious thinking. The path analysis (Figure 1) revealed that narcissism was a stronger predictor of both adaptive and maladaptive coping than over-claiming. It may have resulted from the fact that these two constructs seem to differ in breadth with narcissism being a much broader one. Another possible reason for the difference is a stronger method effect for narcissism. Similarly to coping, narcissism was measured with a self-report inventory. A similar style of responding could explain a part of covariance between the two self-report measures.

There was a significant and moderate relationship between the OCQ and one of the measures of counterproductive thinking: the Personal Superstitious Thinking scale. The relationship was not expected, but it is congruent with the hypothesis that OCQ would be a predictor of cognitive coping strategies. High results on the PST scale mean that the participants think that bad things are going to happen in their life. Inverse relationship between the OCQ and personal superstitious thinking suggests that the higher self-enhancement the lower negative expectations toward the future the person has.

Contrary to expectations, scores on the Behavioral Coping Scale were not only predicted by the OCQ but also by the NPI. The $\mathrm{BC}$ scale generally captures cognitive and behavioral aspects of coping. However, one of the aspects of Behavioral Coping is more emotional in nature, as it stresses eliciting positive emotions and enthusiasm for action, e.g., "When doing unpleasant chores, I make the best of it by thinking pleasant or interesting thoughts", or "When I am faced with a difficult task, I think encouraging thoughts that help me do my best". The results of hi- erarchical regression clearly indicated that OCQ and NPI explained different aspects of Behavioral Coping, which is in accord with the claim about the two distinct aspects of self-enhancement, one better captured by the OCQ and the other better measured by the NPI. However, the two significant predictors of one CTI scale point to the weakness of the present approach which results from the fact that the emotional and cognitive aspects of coping may be so intertwined that it may be difficult to isolate them.

It is worth noting that we did not find a significant correlation between the two measures of self-enhancement. In the original paper where OCQ was presented as the measure of self-enhancement the bias index correlated moderately with narcissism (Paulhus et al., 2003). In the subsequent study a different version of OCQ was used which referred to non-academic topics such as sports, music and movies (Paulhus, Trapnell, 2008). The correlations between the new version and narcissism were weaker and significant only for topics the person valued. The nonsignificant correlation between over-claiming and narcissism might suggest that the two methods capture different aspects of self-enhancement that do not overlap in some samples or for some forms of OCQ.

In sum, the results corroborate Marshall and Brown's (2008) hypothesis concerning the important role of positive illusions in coping with stressful situations. The relationships revealed in the investigation suggest that the impact of self-enhancement on coping is complex. Thus, the conclusions would appear to agree with Paulhus' (1998) conception of self-enhancement as "a mixed blessing".

Received August 19, 2012 


\section{REFERENCES}

ALICKE, M.D., GOVORUN, O., 2005, The Better-Than-Average Effect. In: M.D. Alicke, D.A. Dunning, J.I. Krueger (Eds.), The self in social judgment (pp. 85-106). New York, NY: Psychology Press.

BAUMEISTER, R.F., HEATHERTON, T.F., TICE, D.M., 1993, When ego threats lead to selfregulation failure: Negative consequences of high self-esteem. Journal of Personality and Social Psychology, 64, 141-156.

BECK, A.T., 1976, Cognitive therapy and the emotional disorders. Oxford England: International Universities Press.

BONANNO, G.A., FIELD, N.P., KOVACEVIC, A., KALTMAN, S., 2002, Selfenhancement as a buffer against extreme adversity: Civil war in Bosnia and traumatic loss in the United States. Personality and Social Psychology Bulletin, 28, 184-196.

BONANNO, G.A., VITARO, F., DEKEL, S., 2005, Self-enhancement among high-exposure survivors of the September $11^{\text {th }}$ terrorist attack: Resilience or social maladjustment? Journal of Personality and Social Psychology, 88, 984-998.

CHANG, E. (Ed.), 2008, Self-criticism and selfenhancement: Theory, research, and clinical implications. Washington, DC: American Psychological Association.

CARVER, C.S., SCHEIER, M.F., WEINTRAUB, J.K., 1989, Assessing coping strategies: A theoretically based approach. Journal of Personality and Social Psychology, 56, 267-283.

COHEN, J., COHEN, P., WEST, S.G., AIKEN, L.S., 2003, Applied multiple regression/correlation analysis for the behavioral sciences, $3^{\text {rd }}$ ed. Mahwah, NJ: Lawrence Erlbaum.

COLVIN, C.R., BLOCK J., FUNDER, D.C., 1995, Overly positive self-evaluations and personality: Negative implications for mental health. Journal of Personality and Social Psychology, 68, 11521162 .

ELLIS, A., 1962, Reason and emotion in psychotherapy. Oxford: Lyle Stuart.

EPSTEIN, S., 1990, Cognitive-experiential selftheory. In: L.A. Pervin (Ed.), Handbook of personality: Theory and research (pp. 165-192). New York, NY: Guilford Press.

EPSTEIN, S., 1992, Coping ability, negative selfevaluation, and overgeneralization: Experiment and theory. Journal of Personality and Social Psychology, 62, 826-836.

EPSTEIN, S., 1993, Manual for the Constructive Thinking Inventory. Unpublished manuscript, University of Amherst.

EPSTEIN, S., 2003, A cognitive-experiential selftheory of personality. In: T. Millon, M.J. Lerner (Eds.), Comprehensive handbook of psychology: Vol. 5. Personality and social psychology (pp. 159184). Hoboken, NJ: Wiley.

EPSTEIN, S., MEIER, P., 1989, Constructive thinking: A broad coping variable with specific components. Journal of Personality and Social Psychology, 57, 332-350.

FOSTER, J.D., CAMPBELL, W.K., 2005, Narcissism and resistance to doubts about romantic partners. Journal of Research in Personality, 39, 550-557.

HEINE, S.J., BUCHTEL, E.E., 2009, Personality: The universal and culturally specific. Annual Review of Psychology, 60, 369-394.

HOORENS, V., PANDELAERE, M., OLDERSMA, F., SEDIKIDES, C., 2012, The hubris hypothesis: You can selfenhance, but you'd better not show it. Journal of Personality, 80, 1237-1274.

JOHN, O.P., ROBINS, R.W., 1994, Accuracy and bias in self-perception: Individual differences in selfenhancement and the role of narcissism. Journal of Personality and Social Psychology, 66, 206-219.

KATZ, L., EPSTEIN, S., 1991, Constructive thinking and coping with laboratory-induced stress. Journal of Personality and Social Psychology, 61, 789-800.

KURT, A., PAULHUS, D.L., 2008, Moderators of the adaptiveness of selfenhancement: Operationalization, motivational domain, adjustment facet, and evaluator. Journal of Research in Personality, 42, 839-853.

KWAN, V.Y., JOHN, O.P., KENNY, D.A., BOND, M.H., ROBINS, R.W., 2004, Reconceptualizing individual differences in self-enhancement bias: An interpersonal approach. Psychological Review, 111, 94-110.

KWAN, V.Y., KUANG, L., ZHAO, B.X., 2008, In search of the optimal ego: When self-enhancement bias helps and hurts adjustment. In: H.A. Wayment, J.J. Bauer (Eds.), Transcending self-interest: Psychological explorations of the quiet ego (pp. 43-51). Washington, DC: American Psychological Association.

MACMILLAN, N.A., CREELMAN, C.D., 2005, Detection theory: A user's guide. Mahwah, NJ: Lawrence Erlbaum. 
MARSHALL, M.A., BROWN, J.D., 2008, On the psychological benefits of self-enhancement. In: E. Chang, (Ed.), Self-criticism and self-enhancement: Theory, research, and clinical implications (pp. 19-35). Washington, DC: American Psychological Association.

NECKAR, J., 2000, Factorial structure of the Polish version of the Constructive Thinking Inventory. Poster presented at $10^{\text {th }}$ European Conference on Personality, July 16-20, Kraków.

OTTER, Z., EGAN, V., 2007, The evolutionary role of self-deceptive enhancement as a protective factor against antisocial cognitions. Personality and Individual Differences, 43, 2258-2269.

OETTINGEN, G., GOLLWITZER, P.M., 2002, Turning hope thoughts into goal-directed behavior. Psychological Inquiry, 13, 304-307.

PAULHUS, D.L., 1998, Interpersonal and intrapsychic adaptiveness of trait selfenhancement: A mixed blessing? Journal of Personality and Social Psychology, 74, 1197-1208.

PAULHUS, D.L., HARMS, P.D., BRUCE, M.N., LYSY, D.C., 2003, The overclaiming technique: Measuring selfenhancement independent of ability. Journal of Personality and Social Psychology, 84, 681-693.

PAULHUS, D.L., TRAPNELL, P.D., 2008, Selfpresentation: An agency-communion framework. In: O.P. John, R.W. Robins, L.A. Pervin (Eds.), Handbook of personality psychology (pp. 492-517). New York: Guilford.

RASKIN, R., TERRY, H., 1988, A principal-components analysis of the Narcissistic Personality Inventory and further evidence of its construct validity. Journal of Personality and Social Psychology, 54, 890-902.

RHODEWALT, F., MORF, C.C., 1998, On selfaggrandizement and anger: A temporal analysis of narcissism and affective reactions to success and failure. Journal of Personality and Social Psychology, 74, 672-685.

ROBINS, R.W., BEER, J.S., 2001, Positive illusions about the self: Shortterm benefits and longterm costs. Journal of Personality and Social Psychology, 80, 340-352.

SCHEUER, E., EPSTEIN, S., 1997, Constructive thinking, reactions to a laboratory stressor, and symptoms in everyday life. Anxiety, Stress \& Coping: An International Journal, 10, 3, 269-303.

SKINNER, E.A., EDGE, K., ALTMAN, J., SHERWOOD, H., 2003, Searching for the structure of coping: A review and critique of category systems for classifying ways of coping. Psychological Bulletin, 129, 216-269.

STEED, L.G., 1998, A critique of coping scales. Australian Psychologist, 33, 193-202.

SURBEY, M.K., 2011, Adaptive significance of low levels of self-deception and cooperation in depression. Evolution and Human Behavior, 32, 2940.

TAYLOR, S.E., BROWN, J.D., 1988, Illusion and well-being: A social psychological perspective on mental health. Psychological Bulletin, 103, 193210.

TAYLOR, S.E., GOLLWITZER, P.M., 1995, Effects of mindset on positive illusions. Journal of Personality and Social Psychology, 69, 213-226.

TAYLOR, S.E., KEMENY, M.E., REED, G.M., BOWER, J.E., GRUENEWALD, T.L., 2000, Psychological resources, positive illusions, and health. American Psychologist, 55, 99-109.

TAYLOR, S.E., LERNER, J.S., SHERMAN, D.K., SAGE, R.M., MCDOWELL, N.K., 2003, Portrait of the self-enhancer: Well-adjusted and well-liked or maladjusted and friendless? Journal of Personality and Social Psychology, 84, 165-176.

TAYLOR, S.E., SHERMAN, D.K., 2008, Selfenhancement and self-affirmation: The consequences of positive self-thoughts for motivation and health. In: W. Gardner, J. Shah (Eds.), Handbook of motivation science (pp. 57-70). New York, NY: Guilford.

UJI, M., NAGATA, T., KITAMURA, T., 2012, Narcissism: Its function in modulating self-conscious emotions. Bulletin of the Menninger Clinic, 76, 3, 211-234 


\title{
SEBAPOVYŠOVANIE A COPING: STRATYA PRÍNOSY POZITÍVNYCH ILÚZII
}

\begin{abstract}
J. N e c k a r
Súhrn: Vzt’ah medzi sebapovyšovaním a psychickou adjustáciou je kontroverzný a od publikovania vplyvnej práce Taylora a Browna (1988) je zatial’ otvorený diskusiám. Náś výskum sa zameral na skúmanie vzt’ahu medzi dvoma mierami sebapovyšovania (narcizmus a prehnané nároky) a copingom (konštruktívne myslenie) na vzorke mladých, zdravých dospelých l'udí $(\mathrm{N}=168)$. Štrukturálny model ukázal rovnako silný vzt’ah sebapovyšovania k vysokej a nízkej úrovni copingu, čím potvrdil hypotézu, podla ktorej má sebapovyšovanie tak adaptívny ako aj maladaptívny vplyv. Zistili sa aj rozličné vzory vzt'ahov medzi dvoma mierami sebapovyšovania a copingu, čo podporuje domnienku, že rozpory ohl'adom adaptívnej hodnoty sebapovyšovania sú $\mathrm{z}$ väčšej časti dôsledkom rôznych mier sebapovyšovania.
\end{abstract}

